\title{
BANK CREDITS AND RENT-PRICE RELATION: AN INTERPRETATION ON THE ROLES OF CREDITS IN ECONOMY AND TIME SERIES ANALYSIS WITH STRUCTURAL BREAK
}

\author{
DOI: 10.17261/Pressacademia.2020.1289 \\ JEFA- V.7-ISS.3-2020(2)-p.214-222
}

\section{Esat Dasdemir}

Istanbul Gelisim University, Department of Foreign Trade, Istanbul, Turkey. edasdemir@gelisim.edu.tr, ORCID: 0000-0001-8950-2020

To cite this document

Dasdemir, E., (2020). Bank credits and rent-price relation: an interpretation on the roles of credits in economy and time series analysis with structural break. Journal of Economics, Finance and Accounting (JEFA), V.7(3), p.214-222

Permanent link to this document: $\mathrm{http} / / /$ doi.org/10.17261/Pressacademia.2020.1289

Copyright: Published by PressAcademia and limited licensed re-use rights only.

\begin{abstract}
Purpose- This study argues that interest rate and credit usage will affect rents negatively but prices positively. The study; aims to test, explain, interpret the effect of interest rates on these two variables and offer appropriate policy recommendations.

Methodology- Theory tested on the US housing market with the structural break time series analysis between 2005Q1-2020Q1. Least squares (LS) and Newey-West estimators used, and the interpreted output was the Newey-West estimator.

Findings- According to the results reached, the increase in mortgage interest rates for the 2005Q1-2009Q1 and 2011Q4-2020Q1 period decreases the housing rent / price ratio. For the 2009Q2-2011Q3 period, in which the effects of the 2008 Global Financial Crisis are observed in the model, this relationship is observed positively.

Conclusion- As a result of the predicted model, the impact of credit usage on other economic factors evaluated. Credit usage and interest rates have different effects on prices and rents. This is explained by the substitution relationship between rental and purchase. The study states that interest rates should be evaluated as a tool to balance rents and prices. The study contributes to the literature by revealing the accuracy of this supervisory power attributed to interest rates and bank loans.
\end{abstract}

Keywords: Credit usage lease and purchase relationship, rent-price relationship, financial system, effect of interest rate on rent and price JEL Codes: E51, G10, H81

\section{BANKA KREDILERI VE KIRA-FIYAT ILIŞKISI: KREDILERIN EKONOMIDEKI ROLLERI ÜZERINE BíR YORUM VE YAPISAL KIRILMALI ZAMAN SERILERI ANALIZi}

\section{ÖZET}

Amaç- Bu çalışma faiz ve kredi kullanımının kiraları olumsuz yönde etkileyeceğini, ancak fiyatları olumlu etkileyeceğini savunmaktadır. Çalışma; faiz oranlarının bu iki değişkene etkisi test etmek, açıklamak, yorumlamak ve uygun politika önerisi sunmayı amaçlamaktadır.

Yöntem- Teori, ABD konut piyasası üzerinde 2005Ç1-2020Ç1 dönemleri arasında yapısal kırılmalı zaman serileri analizi ile test edilmiştir. En küçük kareler ve Newey-West tahmincileri kullanılmış, yorumlanan çıktı ise Newey-West tahmincisi olmuştur.

Bulgular- Ulaşılan sonuçlara göre 2005Ç1-2009Ç1 ve 2011Ç4-2020Ç1 dönemi için mortgage faiz oranlarındaki artış konut kira/fiyat oranını azaltmaktadır. Modelde 2008 Küresel Finansal Krizin etkilerinin görüldüğü 2009Ç2-2011Ç3 dönemi için ise bu ilişkinin doğrusal olduğu görülmektedir.

Sonuç- Tahmin edilen model sonucu kredi kullanımının diğer ekonomik unsurlara etkisi değerlendirilmiştir. Kredi kullanımı ve faiz oranlarının, fiyat ve kiralar üzerinde farklı etkilere neden olmaktadır. Bu durum kiralama ve satın alma arasındaki ikame ilişkisi ile açıklanmıştır. Çalışma, faiz oranlarının kiralar ve fiyatları dengeleyecek bir araç olarak değerlendirilmesi gerektiğini belirtmektedir. Çalışma faiz oranları ve banka kredileri üzerine atfedilen bu denetim gücünün doğruluğunu ortaya koyarak literatüre katkı yapmaktadır.

Anahtar Kelimeler: Kredi kullanımı kiralama ve satın alma ilişkisi, kira-fiyat ilişkisi, finansal sistem, faiz oranının fiyat ve kiralara etkisi JEL Kodları: E51, G10, H81 


\section{GiRiş}

Finansal araçların çeşitlenmesi, bankacılık sisteminin gelişmesi ve teknolojik ilerlemeyle birlikte günümüzde, fon arz ve talep eden unsurların buluşmasını oldukça kolaylaştırmıştır. Bireyler küçük ölçekli, günlük işlemlerini dahi kredi kartı kullanarak sürdürebilmektedir. Doğal olarak bu durum ve bu durumun sonuçları pek çok tartışmanın ana öğesi olmuştur.

Olağan bir ekonomide fiyat ve kiraların doğrusal hareket etmesi gerekmektedir. Oysa bu çalışmaya göre faizler ve banka kredileri fiyatlar üzerinde doğrusal, kiralar üzerinde ters yönlü etkide bulunmak yoluyla söz konusu beklentiyi kırmaktadır. Bu çalışma ilk önce türlerine göre banka kredilerinin piyasaya etkilerine değinmeyi ardından bireylerin kredi kullanma nedenlerinden yola çıkıp kredi kullanımı sonucunda varlık fiyat ve kiralarının ne gibi bir tepki vereceğini analiz ederek söz konusu durumu sistematik bir kanuna dönüştürmeyi amaçlamaktadır.

İlk bölümde faizler ve banka kredileri ele alınmıştır. İletişim teknolojilerinin gelişimiyle bankacılık sektöründe yaşanan dönüşüm, kredilerin ve borçlanma araçlarının ekonomik işlemlerde artan önemi ve değişen rolleri ele alınmıştır. Temel tüketimlerin bile borçlanarak gerçekleştirilme olanağının artması, borçlanma maliyetleri ve talep ilişkisini güçlendirmiştir. Bu çalışma, tüketicinin kredi kullanım nedeni bir malın iyeliğini satın almak biçiminde açıklamaktadır. Bu açıklamanın altında yatan varsayım tüketicinin kredi maliyetine kira ödemesinden kaçınmak amacıyla katlanacağıdır. Dolayısıyla tüketici için bir varlığın a- iyeliğini satın almak b- belirli bir süre için kullanım hakkını satın almak diğer bir deyişle kiralamak üzere iki seçenek bulunmaktadır. Bu ikame ilişkisi nedeniyle kredi kullanımı maliyetinin ana unsuru olan faizler, fiyatlar ile doğrusal, kiralar ile ters yönlü ilişki içindedir. Çalışma kredi kullanımı, kira ve fiyat arasındaki ilişkinin çeşitli kredi türlerine göre farklılık göstereceğini de öngörmektedir.

İkinci bölümde fiyat-kira ilişkisi derinlemesine ele alınmıştır. Buna göre sağlıklı bir ekonomide varlık fiyatları ve kiralarının doğrusal hareket etmesi beklenir. Ancak faiz oranlarındaki anlık düşüşler ve kredi hacminin kontrolsüz genişlemesi fiyat-kira ilişkisini ters yönlü duruma getirmektedir. Bu durumun nedeni ve etkileri incelenmiştir. Daha önce yapılan çalışmalar sağlıklı bir ekonomi için kira enflasyonunun kira dışı enflasyondan yüksek olmasını öngörmüştür. Ancak bu çalışma bu bağlantının sürdürülebilir olmadığını öngörmektedir. Söz konusu değişkenler yerine kira ve fiyat ilişkisinden yola çıkarak sağlıklı bir varsayım ortaya koymak istenmiştir. Buna göre sağlıklı bir ekonomi için kiralar ve fiyatlar eş doğrultuda seyretmelidir. Ancak fiyatlardaki artış o malın üretimini artırdığı ve ekonomide miktarı artan bu malın getirisi olan kiraların düştüğü görülmektedir. Dolayısıyla kira/fiyat oranını eş doğrultuda tutmak için faizler bir araç olarak kullanılmalıdır.

Üçüncü bölümde çalışmanın hipotezi ekonometrik model ile sınanmıştır. Zaman serisi yöntemi kullanılarak yapılan tahmin 2005Ç1-2020Ç1 dönemi arası ABD konut piyasası üzerinde gerçekleştirilmiştir. Tahmin sonucu modelde yapısal kırılma tespit edilmiştir. Yapılan testler sonucu yapısal kırılmanın 2009Ç2-2011Ç3 dönemi arası olduğu anlaşılmıştır. 2008 Küresel Finansal Krizin etkisinin görüldüğü bu dönem dışında mortgage faizlerindeki artışın, ABD konut kira/fiyat oranını azalttığı sonucuna varılmıştır. Yapısal kırılmanın olduğu dönemde ise bu ilişki pozitif eğimlidir.

Çalışmanın sonuç ve öneri kısmında ise faiz ve banka kredilerinin politika yapıcı tarafından doğru biçimde ve daha etkin bir araç olarak kullanılması için önerilerde bulunulmuştur. Kredi maliyetlerinin vadelerine göre ayrılarak değerlendirilmesi ekonomiyi pek çok iktisadi amaca ulaştırabilecek bir uygulama olacaktır. Bu iktisadi amaçlardan bazıları; yurtiçi tasarruf oranının artması, sanayinin gelişmesi, aşırı kapasite üretim nedeniyle etkin olmayan sektörlerdeki baskının azaltılması, düşük ölçekli üretim yapması nedeniyle üretim maliyetlerinin yüksek olduğu sektörlerde üretimi artırmaktır.

\section{BANKA KREDILERi}

Belirli bir vade sonunda faiz karşılığı ile birlikte bankaya geri ödenmek koşuluyla ödünç alınan banka kredileri finansal sistemin aktarım çarklarını döndüren önemli bir yatırım ve finansman aracıdır. Diğer araçlar gibi banka kredilerinin kullanımındaki temel hedef fon arz ve talepçilerini buluşturmak, parasal aktarım mekanizmasına işlerlik kazandırmaktır. Öte yandan, banka kredilerinin diğer finansal araçlardan en ayırt edici özelliği kullanım kolaylığı ve yaygınlığıdır. Firmaların bilançolarına bakıldığında banka kredilerinin ağırlıkta olduğu görülmektedir(Balkaş, 2004, p. 1). Son yıllarda ivediyle gelişen ve kullanımı yaygınlaşan teknolojinin, geleneksel alışveriş alışkanlığını değiştirmesi ve kredili alışveriş ile banka kartı kullanımının kolaylaşması gibi durumlar göz önüne alındığında en ufak tüketimin dahi banka kredileriyle yapılabileceği anlaşılmaktadır. Bu durum, bir politika aracı olarak banka kredilerinin etkinliğini de artırmıştır. Ayrıca banka kredilerinin finansal sistem içerisinde bu denli yaygın oluşu ve yerini başka araçlara bırakamayacak, başka araçların da banka kredilerinin yerini dolduramayacak oluşu finansal sistemin banka kredileri ve bankacılık sektörü ile ortak anılmasına neden olmuştur. Dolayısıyla banka kredileri, finansal sistemin durumunu anlatan en önemli ve en çok kullanılan göstergelerden biri konumuna gelmiştir. Öyle ki Kar ve Pentecost (2000), Ceylan ve Durkaya (2010), Kaya, Gülhan ve Güngör (2013), Çeştepe ve Yildirim (2016) çalışmalarında finansal genişlemenin göstergesi olarak banka kredilerine vurgu yapmaktadırlar. 
Bu gün pek çok çalışmanın temel konusu olsa da finans, bankacılık ve para kesimi önceki dönemlerde göz ardı edilmiştir. Geçmişte, Neoklasik büyüme teorileri finansal genişlemeye herhangi bir rol biçmemiş(Çeştepe \& Yildirim, 2016, p. 13), Keynesci görüş ise para politikalarını göz ardı etmiş, bunun sonucu olarak finansal sistem ve finansal araçlar ekonomide hak ettiği ilgiyi uzun zaman görmemiştir. Ancak bu durumu petrol krizleri bozmuştur. Özellikle petrol krizlerinden sonra önemi anlaşılan para politikaları geçmişe kıyasla günümüzde çok daha ön plandadır. Belki de bunun en büyük göstergesi 2008 Dünya Krizine neden olan yetersiz talep sorununun mali politikalarla değil, para politikaları öncülüğünde çözülmesidir. Amerikan Federal Bankası (FED) 2008 yılı başında sekiz yüz milyon dolar seviyelerinde bulunan parasal tabanı 2014 yılında dört milyar dolar seviyelerine çıkartmış (Monetary Data: FRED St. Louis Fed, 2020) ve FED'in uyguladığı politikalar sonrası faizler tarihi seviyelere düşmüştür(Arslan \& Kanık, 2012, p. 4).

Para politikaları ve finansal sistem uygulamada uzunca bir dönem geri planda kalmış olsa bile, finansal sitemin büyüme ve diğer reel değişkenler üzerine etkisi konusundaki düşünce ve modeller yüzyıl öncesine uzanabilmektedir. Konu üzerinde Bagehot (1873) ilk kez durmuş ve onun ardından Schumpeter (1911) tarafından ekonomik büyümenin motoru olarak kabul edilen inovasyonu kolaylaştırdığı için finansal sistemin dolaylı olarak büyümeye katkı yapacağı vurgulanmıştır. King ve Levine (1993) Schumpeter'in çalışmasına paralel olarak, finansal sistemin verimlilik üzerine yaptığı etkilere vurgu yapmışlardır. Bunlarla birlikte Robinson (1952) ve Patrick (1966) gibi teorisyenler de finansal genişleme ve büyüme arasındaki nedensellik ilişkisine odaklanmıştır. Ülkemiz günceline gelindiğinde ise Kaya, Gülhan ve Güngör (2013) 1998-2009 dönemini kapsayan gözlemsel çalışmaları sonucu Türkiye'de finansal kesimin reel sektörü ve büyümeyi önemli derecede etkilediği sonucuna ulaşmışlardır. Bu çalışmanın hipotezi olan fiyat, faiz ve kredi değişkenleri arasındaki ters yönlü nedensellik ilişkisinin anlaşılması için kredi kullanımı ve büyüme (üretim) arasındaki bu bağlantı önem arz etmektedir(Bkz. 2.1.).

King ve Levine'nin vurguladığı gibi, finansal sistemin, verimlilik üzerine ciddi ölçüde etkisi bulunmaktadır. Yalnız, finansal piyasalar, fon aktarımı yoluyla ekonomik etkinliği artırmakla kalmayıp verilen kredilerin ve diğer finansal araçların niteliklerine göre ekonomide reel değişkenleri etkileme ve ekonomiye yön verme gücünü de elinde bulundurur. Söz gelimi, kısa vadeli ve düşük miktarlı kredilerin maliyetlerindeki bir düşüş ya da kredi kartı kullanımını kolaylaştıran bir uygulamalar günlük tüketim malları gibi bu tür kredilerin hitap ettiği ürünlerin talebi ve fiyatını artırırken, uzun vadeli kredilerdeki bir maliyet düşüşü konut ve taşıt gibi ürünlerin piyasalarını genişletecektir. Kredilerin piyasa talebini, dolayısıyla üretim ölçeğini belirlediği göz önüne alınırsa; finansal piyasalar, piyasalar arası üretim maliyetlerinin önemli bir belirleyicisidir. Banka kredilerinin, bankacılık kesiminin ve dolayısıyla para politikalarının bu öneminden dolayı para politikalarının etkin kullanımı hızla artmış ve artan bu kullanım yoğunluğunun da bir sonucu olarak reel piyasalar parasal işlemlere, finans ve bankacılık sektörlerine daha duyarlı biçime gelmiştir.

Finans ve bankacılık kesiminin piyasa içindeki rolü daha somut bir söylemle şu biçimde açıklanabilir; finans ve bankacılık sektörü tarım, sanayi, hizmet sektörleri gibi reel değer üretimine doğrudan katkı yapmaz. Yalnız, reel değer üreten sektörlere kaynak aktarımı yapmak yoluyla reel üretime dolaylı bir katkı sağlar (Alkan, 2016, p. 118). İşte bu dolaylı katkının ne denli olacağı bankacılık sektörünün kaynak aktarımı işindeki etkinliğe, bu kaynakların hangi sektörlerde kullanıldığına, kaynakları kullanan işletmelerin niteliklerine ve son olarak kaynak verme; diğer bir deyişle fonlama maliyetlerine göre değişiklik gösterir. Kredi maliyetleri ise büyük ölçüde para politikaları ve finansal piyasaların işleyişiyle belirlenir.

Özet olarak finansal sitemin en önemli aktörü olan bankacılık kesimi, reel üretim yapan sektörlerde etkinliği artırma görevini üstlenmektedir. Bu konuya şöyle de bakılabilir; bankaların fonlama işlevi, eksik sermaye nedeniyle atıl durumda kalan girişimci faktörünü piyasaya kazandırır. Özellikle gelişmekte olan ülkelerde kıt ve etkin kullanılamayan girişimcilik faktörünün etkin biçimde kullanımı işgücü talebini de artırıp, işsizliği azaltmak yoluyla çıktı miktarını çoğaltacaktır. Bankaların girişimciyi, ticari kredi yoluyla fonlaması ekonomik etkinliği ve büyümeyi artırdığı gibi, girişimci miktarındaki ve işgücü talebindeki artış girişimci karlarını düşürürken, ücretleri yükselterek gelir dağılımındaki dengeyi sağlamlaştıracaktır

Anlaşılacağı üzere banka kredileri tüketicilerin ve üreticilerin fon taleplerini karşılamak için tercih ettikleri bir kaynaktır. Dolayısıyla banka kredilerinin ekonomiye etkileri üzerinde duran bir takım gözlemsel ve teorik çalışmalarda krediler tüketim ve ticari krediler olarak iki ana kola ayrılmaktadır. Alioğulları, Başkaya, Bulut ve Kılınç (2015) 2003-2015 yılları arası Türkiye üzerinde yaptıkları gözlemsel çalışmada tüketim ve ticari kredilerin cari açıkla ilişkisini incelemiş; tüketim kredilerinin cari açığı artırıcı etkide bulunduğu, ticari kredilerin ise istatistiki olarak anlamlı bir etkisinin olmadığı sonucuna ulaşmışlardır. Öğünç ve Sarikaya (2015) ise bu iki kredi türünün fiyat artışları üzerine etkisini inceledikleri çalışmalarında, tüketici kredilerinin ticari kredilere kıyasla fiyat artışlarının daha güçlü bir destekcisi olacağına dikkat çekmektedir.

Kredi türlerinin etkileri arasındaki farları ortaya koymak için yapılan çalışmalar göz önüne alındığında kullanım amacına göre ticari ya da tüketim kredisi olması, kredilerin fiyatlar üzerindeki etkisini değiştireceği önsel olarak anlaşılmaktadır. Bu bölümde söz konusu iki kredi türü ve ekonomi üzerine potansiyel etkilerinden kısaca bahsedilecektir. 


\subsection{Tüketici Kredisi}

Bir miktar faiz ödemesi karşılı̆ında bireylerin tüketimlerini fonlayan kredi türüdür. Dolayısıyla bu tür kredilerin kullanımı sonrası ekonomi üzerinde duyulması beklenen ilk etki talep ve fiyat artışıdır. Bu durumda üretim artışı, piyasa fiyat artışını takip edecektir.

Tüketici kredileri vadesine ve kullanım biçimine göre değişik ürünler için talep yaratabilme gücünü bünyelerinde barındırmaktadırlar bu nedenden dolayı tüketim kredileri piyasaya yön veren bir ekonomi aracı konumundadır. Söz gelimi; uzun vadeli mevduatlara uygulanan faiz oranlarındaki bir artış, konut kredisi gibi uzun vadeli kredilerin maliyetlerini ve faiz ödemelerini artıracak, dolayısıyla da konut talebini kısacaktır. Diğer yandan kısa dönemli mevduatlara ve kredi kartı gecikme faiz oranlarına uygulanacak faiz indirimi bireylerin gündelik tüketimlerini artıracaktır. Makroekonomik açıdan düşünüldüğünde tüketici kredilerine yönelik politikaların temel amacı, her hangi bir sektörde aşırı talep nedeniyle ortaya çıkan maliyetli üretim durumuna engel olmak ve sektörler arası karlılık farklılıklarını engellemek olmalıdır. Bu bağlamda, ekonomide aşııı kapasite üretimden dolayı birim maliyetlerin yüksek olduğu sektöre; vadesine göre mevduatlara uygulanacak faiz oranları ile cezalandırılmalıdır.

Tüketici kredilerinin diğer bir olumsuz etkisi ise uzun vadeli olan tüketici kredilerinin gelecek dönemlerde efektif talebi daraltmasıdır. 2008 Küresel Finansal Krizi nedenlerinden biri de bu durumdur. Diğer bir deyişle tüketici kredileri, kredi maliyet ve risklerini tüketiciye yükleyerek; bireylerin ekonomik özgürlüklerini daraltmak, gönülsüz ve verimsiz çalışmaya zorlamak gibi sonuçlar doğurabilir. Bu durum daha az ücrete daha çok çalışmak isteyen emek arzcıları ya da tüketici kredisi kullanıcıları ile emek talepçisi olan firmalar arasında gelir aktarımına neden olmaktadır(Daşdemir, 2017, p. 69). Dolayısıyla tüketici kredileri kullanımıyla birlikte kredinin hitap ettiği sektörde bulunan firmaya iki açıdan kazanç sağlamaktadır 1- talep ve fiyat artışı, 2borç yükündeki artış nedeniyle emek arzı artışı ve ücretlerin düşüşü.

\subsection{Ticari Krediler}

Firmalarca üretim hedefiyle kullanılan ticari krediler, firmaların en önemli yabancı kaynaklarından biridir. Dolayısıyla öz sermayenin alternatifi olan ticari krediler, üretim faktörü olarak sermaye maliyetinin bir belirleyicisidir. Bu tür kredilerdeki maliyet düşüşü öz kaynak yetersizliğinden dolayı, piyasada atıl kalan girişimci faktörünün piyasaya kazandırılmasını sağlayacaktır.

Ticari kredilerin diğer bir önemi ise, yine sermayenin maliyetini belirlemek yoluyla, sermaye yoğun üretim yapan sektörlerin üretim maliyetlerini; dolayısıyla bu sektörlerin üretim ölçeklerini belirlemesidir. Diğer bir deyişle ticari krediler, sanayileşmenin belirleyicilerinden biridir.

Bu iki özelliğinden dolayı ticari krediler, gelişmekte olan ülkeler için kritik bir konumdadır.

Yine ticari kredilerin diğer bir özelliği, kullanıcısı olan girişimci ya da firmanın, bu borç yükü dolayısıyla daha çok, verimli, az maliyetle üretim yapma isteğine katkı sağlamasıdır.

\subsection{Banka Kredileri Üzerine Politika Önerileri}

Bu çalışma banka kredileri ve onun alt türlerine yönelik politikaların şu biçimde olması gerektiğini belirtmektedir;

- Banka kredilerine yönelik politikaların hedefi fiyat ve kiraları dengeleyip aşırı fiyat ve kira artışlarını önlemektir.

- Tüketici kredilerine yönelik politikaların hedefi sektörler arası aşırı karlılığı dengelemek, bir sektörde aşırı fiyatlanmadan kaynaklanan maliyetli üretim yapılmasını engellemektir.

- Ticari kredilere yönelik politikaların hedefi piyasada atıl durumda kalan girişimci faktörünü piyasaya kazandırmak, üretimde sermaye kullanımını artırarak emeğin verimliliğini yükseltmek ve sermaye yoğun üretim yapan kesimlere maliyet kolaylığı sağlamak yoluyla sanayileşme gibi hedeflere öncülük etmektir.

Öte yandan Türkiye Ekonomisi için banka kredileri üzerine planlı bir politika izlenmediği ve piyasa üzerine önemli etkileri bulunan bu aracın kontrolünü piyasaya bıraktığı söylenebilir. Bilgin ve Kartal, (2009) Türkiye için 2002 ve 2008 yıllarını kapsayan çalışmalarında genişleyen kredi hacmi içindeki payını artıran tüketici kredilerine dikkat çekmiştir. Söz konusu çalışmaya göre bankalar proje finansmanı şeklindeki yatırım ve ticari krediler yerine, tüketim finansmanı içeren bireysel kredilere yönelmektedir. Bu durum gelişmekte olan ülke konumundaki Türkiye için ciddi bir engel oluşturmaktadır. Özellikle tüketim kredilerinde konut kredisi oranının çokça yüksek olması, bu sektörde verimsiz üretime neden olmakla kalmayıp; diğer sektörlerdeki talebi emerek, başka sektörlere zarar vermektedir. 


\section{FIYAT-KIRA YAKLAŞIMI: KREDI KULLANIMI SONRASI FIYAT VE KIRA ILIŞKISi ÜZERINE}

Bu çalışma faiz, kira ve fiyat ilişkisini açıklamaktadır. Bireyler bir varlığın iyeliğini ya da geçici kullanım hakkını satın almak gibi birbirinin yerine ikame edilebilir iki seçenek arasında karar vermekle yükümlüdür. Bu kararı belirleyen en önemli etkenlerden biri borçlanma koşullarıdır. Para politikaları banka mevduatlarını, banka mevduatları ise banka kredileri yoluyla konut talebini etkilemektedir (Mishkin, 2001, s. 653). Dolayısıyla, günümüzde en yaygın borçlanma aracı olan banka kredileri; bireylerin ve firmaların alacakları satın alma ya da kiralama kararı üzerinde güçlü bir belirleyicidir.

Özel durumlar görmezden gelinirse, rasyonel tüketicilerin kredi alarak faiz karşllığına katlanması durumu, ancak kira masrafından kaçınmak için yapacağı bir işlemdir. Diğer bir deyişle rasyonel davranan tüketiciler kira ödemek için değil, varlığın iyeliğini satın almak için kredi kullanacaklardır. Bununla birlikte satın almanın kazancı, satın alınan varlığın değerindeki artış şeklinde de ortaya çıkacaktır. Dolayısıyla tüketici; bir varlığın kirası, o varlığın değerindeki artış ve faiz maliyetleri toplamından küçükse kiralamayı seçmelidir.

Türkiye'de bankacılık sektörü ve kredi hacmi genişlemeleriyle birlikte özellikle son yıllarda banka kredileri ve fiyat artışları üzerine pek çok gözlemsel çalışma yapılmıştır. Arslan ve Yapraklı (2008) 1983-2007 yılları için yaptıkları gözlemsel çalışmalarında fiyat artışının banka kredilerine negatif, banka kredilerinin ise fiyat artışlarına pozitif etkide bulunduğu sonucuna ulaşmışlardır. Yalnız, diğer çalışmalar gibi, kredi kullanımının yol açtığı fiyat ve kira ilişkisi üzerinde durmamıştır.

Arslan ve Kanık (2012) konut piyasası için yaptıkları gözlemsel çalışma sonucu sağlıklı bir piyasada kira enflasyonunun, kira dışı enflasyondan yüksek olması gerektiğine vurgu yapmıştır. Söz konusu çalışmada kiraların konut talebine ve dolayısıyla konut fiyatına neden olacağı belirtilmiş, fiyatların kiralarla birlikte artacağı imasında bulunulmuş, yalnız kira ve fiyatlar arasında ters yönlü bir ilişkinin varlığı üzerinde durulmamıştır. Bu çalışma, kredi kullanımı sonucu kira ve fiyatların negatif ilişki içinde olabileceğini vurgulamakta ve bu ilişkinin olası sonuçlarını yorumlamaktadır.

Kira ve fiyat karasındaki bu negatif ilişkinin iki ana nedeni bulunmaktadır. Bu nedenler, ya da etkiler, alt başıklar halinde gözden geçirilecektir.

\section{1. Üretim Etkisi}

Kredi kullanımı sonrası açığa çıkan fiyat artışları üreticiyi cezbedecek, üretim artışını ardından sürükleyecektir. Bu durumda, piyasada bollaşan malın getirisi, diğer bir deyişle kiralar düşecektir.

Bu durum Tobin (1969)'in q Teorisiyle de açıklanabilir. Buna göre borçlanmanın maliyetindeki azalma, yenileme maliyetlerini düşürecek ve ürünün q değerini artıracaktır. Ürünün q değeri birden çok olduğunda ise, üretici bu ürün için yatırımları artıracak ve ürünün üretimi artacaktır. Bu durumda piyasada bollaşan ürünün getirisinin de azalması beklenir.

Söz gelimi, ekonomide konut kredilerindeki bir düşüş, konut talebini ve dolayısıyla fiyat ve üretimini artıracak ve konut sayısındaki artış konut kiralarını düşürecektir. Diğer değişkenler sabitken, böylesi bir durumda, konut başına düşen kira getirisi azalmış olacaktır.

\section{2. İkame ilişkisi}

Daha önce vurgulandığı üzere rasyonel birey, ancak kira maliyetinden kurtulmak için faiz giderine katlanacaktır. Şu durumda bireyin belirli bir faiz giderini göze alarak borçlanıp ürünün iyeliğini alma ya da kira karşılı̆̆ı ödeyip ürünün kullanım hakkını belirli bir süre için satın alma gibi birbiri yerine ikame edilebilir iki seçeneği vardır. Diğer değişkenler sabitken, bu iki seçenekten birini seçen birey, öbürünün talebini düşürmektedir. Dolayısıyla bu ikame ilişkisi kiralar ile faiz ve fiyat arasında ters yönlü bir bağlantıya neden olmaktadır.

\section{MODEL VE YÖNTEM}

Çalışma kapsamında ortaya atılan soyut söylemlerin somut kanıtları ortaya konmuştur. Bunun için Amerika Birleşik Devletleri(ABD) ölçeğinde, konut piyasalarını kapsayan ekonometrik sınama yapılmıştır. Kurulan modelin amacı konut faizlerindeki artışın kira ve fiyatlar üzerindeki etkisini ölçmektir. 2005 ilk çeyrek (2005Ç1) ve 2020 ilk çeyreği (2020ç1) dönem aralığını kapsayan modelde kullanılan seriler ABD Federal Bankası veri tabanından (Federal Reserve Economic Data, FRED) alınmıştır. Modelde kullanılan değişkenlerin gösterimi ve tanımı Tablo 1'de verilmiştir.

Tablo 1: Değişkenlerin Tanımı

\begin{tabular}{ll}
\hline Değişken & Tanım \\
\hline $\mathrm{R}$ & Mortgage faiz oranı (ABD ortalaması) \\
\hline $\mathrm{KF}$ & ABD konut kira endeksinin konut fiyat endeksine oranı \\
\hline
\end{tabular}


Tahmin edilmek istenen model aşağıdaki gibidir:

$\triangle L K F_{t}=\beta_{0}-\beta_{1} \triangle L R_{t}+\beta_{2} k \Delta L R_{t}+\omega_{t}$

Modelde değişkenlerin adlarına eklenen " $\mathrm{L}$ " göstergesi değişkenin logaritmasının alındığını, " $\triangle$ " göstergesi serinin türevinin alındığını belirtmektedir. " $k \triangle L R$ " değişkeni logaritması ve ardından türevi alınmış " $R$ " değişkenini için kurulan kukla değişkeni ifade eder. " $\beta_{0}$ " sabit katsayı, " $\beta_{1}$ " ve " $\beta_{2}$ " önlerinde bulundukları değişkenlerin katsayılarını, " $\omega_{t}$ " ise kalıntıları ifade etmektedir. Model ve ilgili testler Stata 16 Paket Programı ile tahmin edilmiştir.

\subsection{Birim Kök Testi Sonuçları}

Modelde kullanılan serilerin durağanlıklarına ilişkin yapılan Genişletilmiş Dickey-Fuller (1979) (Augmented Dickey-Fuller, ADF) birim kök testi sınanmıştır. Sınama sonuçlarında değişkenlerin birinci farklarının durağan olduğu görülmüştür.

Tablo 2: ADF Birim Kök Testleri

\begin{tabular}{llll}
\hline Test & & LKF & Li \\
\hline \multirow{2}{*}{ Düzey } & Düzey & 0.5779 & 0.7666 \\
\cline { 2 - 4 } & Birinci Gecikme & 0.2659 & 0.6950 \\
\hline \multirow{2}{*}{ Birinci Fark } & Düzey & 0.0000 & 0.0000 \\
\cline { 2 - 4 } & Birinci Gecikme & 0.0000 & 0.0001 \\
\hline
\end{tabular}

\subsection{Yapısal Kırılmanın Tespiti ve Kukla Değişken Sonrası Elde Edilen Model}

Test ölçeğinin 2008 Küresel Finansal Krizini kapması nedeniyle yapısal kırılma ya da kırılmaların modelde yer alacağı çıkarımı önsel olarak yapılabilir. Yapısal kırılmayı içsel olarak ölçen ve boş hipotezi yapısal kırılma olmadığı yönünde olan Wald Testi (Donald W. K. Andrews, 1993, p. 837) sonucuna göre \%5 önem düzeyinde yapısal kırılma vardır ve yapısal kırıma tarihi 2009'un ikinci çeyreği olarak bulunmuştur. Yapısal kırılmanın grafiksel olarak gösterimi şekildeki gibidir;

\section{Şekil 1: Yapısal Kırılmanın Grafik Üzerinde Gösterimi}

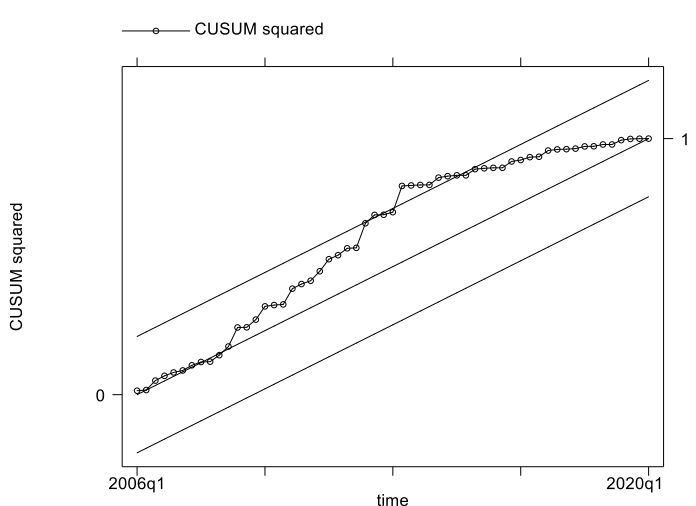

Şekil 1'den görüleceği üzere, yapısal kırılma bir dönem yaşandıktan sonra, tekrar düzeyine geri dönmektedir. 2008 Krizi sonrası 2009'un ilk çeyreğinde kendini somut olarak gösteren yapısal kırılmanın çözümü için kukla değişkenler türetilerek ideal model tespit edilmek istenmiştir. Hem sabit parametrede $\left(\beta_{0}\right)$, hem de $\triangle L R$ değişkeni parametresi üzerindeki yapısal kırılma etkisini ölçmek maksadıyla modele iki kukla değişken eklenmiş, bunlardan $\beta_{0}$ için türetilen kukla değişkenin anlamsız çıkması üzerine modelden çıkarılmıştır. $\beta_{0}$ için kurulan kukla değişken (KU) 2019 2. Çeyreği ile 2011 3. Çeyrek arası için 1, diğer dönemler için 0 şeklinde kurulmuştur. $\triangle L R$ kukla değişkeni olan $k \triangle L R$ ise $\triangle L R$ değişkeninin KU değişkeni ile çarpımı sonucu oluşturulmuştur. Yalnızca $k \triangle L R$ kukla değişkeni eklendiğinde yapısal kırılma sorunu çözülmüştür. Yapısal kırıımanın çözüldüğü Şekil 2'de görülmektedir. 
Şekil 2: Yapısal Kırılmanın Düzeltilmesinden Sonra Modelin Grafiği

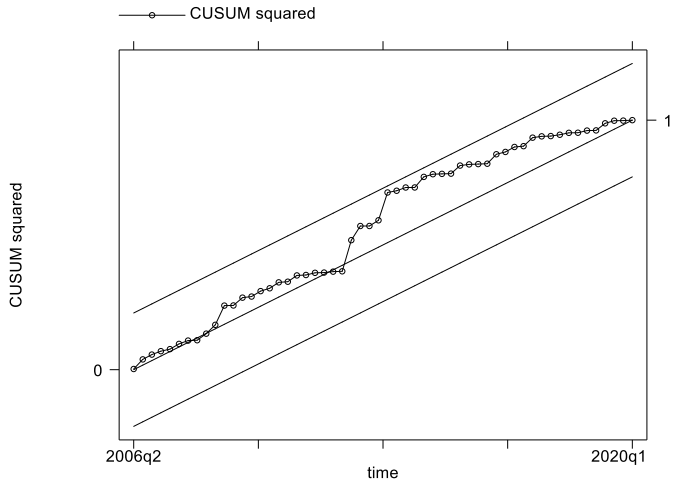

\subsection{Varsayımdan Sapmalar ve Düzeltilmesi}

Tahmin edilen modelin varsayımdan sapmalarının tespiti için yapılan testler ve sonuçları aşağıda verilmiştir.

Tablo 3: Varsayımdan Sapmaların Testleri ve Sonuçları

\begin{tabular}{|c|c|c|c|}
\hline Test & & P Değeri & Sonuç \\
\hline \multirow{2}{*}{ Normal Dağılım } & Jarque-Bera (1987) & 0,89 & \multirow{2}{*}{$\begin{array}{l}\text { Boş hipotez reddedilememiştir. } \\
\text { Kalıntılar normal dağılmaktadır. }\end{array}$} \\
\hline & Skewness/Kurtosis & 0,84 & \\
\hline \multirow{2}{*}{ Heterokedasite } & Breusch-Pagan (1979) & 0,11 & \multirow{2}{*}{$\begin{array}{l}\text { Boş hipotez reddedilememiştir } \\
\text { Heterokedasite sorunu yoktur. }\end{array}$} \\
\hline & White (1980) & 0,52 & \\
\hline \multirow{2}{*}{ Otokorelasyon } & Durbin-Watson (1950) & 0,00 & \multirow{2}{*}{$\begin{array}{l}\text { Boş hipotez reddedilmiştir. } \\
\text { Otokorelasyon sorunu vardır. }\end{array}$} \\
\hline & Breusch (1978) - Godfrey (1978) & 0,00 & \\
\hline
\end{tabular}

Sonuçlara göre modelde normal dağılım ve heterokedasite sorunu bulunmazken otokorelasyon sorunu bulunmaktadır. Otokorelasyon sorununu düzelten Newey-West (1987) tahmincisi kullanılmıştır.

Newey-West tahmincisinde kullanılacak maksimum gecikmenin belirlenmesi için gecikme düzeylerine göre otokorelasyon testleri yapılmış ve 42 . gecikmeden sonra otokorelasyon sorunu olmadığı anlaşılmıştır. Dolayısıyla Newey-West tahmincisi için kullanılan maksimum gecikme 42 olarak seçilmiştir.

\subsection{Modelin Tahmini}

Modelin tahmin çıktıları aşağıdaki gibidir.

Tablo 4: Tahmin Çıktıları

\begin{tabular}{lllll}
\hline Yöntem & Gösterge & Sabit katsayı & \multicolumn{1}{c}{$\Delta \boldsymbol{L}$} & \multicolumn{1}{c}{$\boldsymbol{k} \boldsymbol{L} \boldsymbol{R}$} \\
\hline \multirow{3}{*}{$\begin{array}{l}\text { En Küçük Kareler } \\
\text { (EKK) }\end{array}$} & Katsayı & 0,0037 & $-0,1579$ & 0,2218 \\
\cline { 2 - 5 } & Standart Hata & 0,0029 & 0,0594 & 0,1240 \\
\cline { 2 - 5 } & t Değeri & 1,25 & $-2,66$ & 1,79 \\
\cline { 2 - 5 } & P Değeri & 0,217 & 0,010 & 0,079 \\
\hline \multirow{2}{*}{$\begin{array}{l}\text { Newey-West } \\
\text { (Maksimum } \\
\text { Gecikme 42) }\end{array}$} & Katsayı & 0,0037 & $-0,1579$ & 0,2218 \\
\cline { 2 - 5 } & Standart Hata & 0,0043 & 0,0780 & 0,1214 \\
\cline { 2 - 5 } & t Değeri & 0,84 & $-2,02$ & 1,83 \\
\cline { 2 - 5 } & P Değeri & 0,402 & 0,048 & 0,073 \\
\hline
\end{tabular}

Tahmin çıktılarına göre her iki yöntemde de sabit katsayı anlamsızken, $\triangle L R$ katsayısı \%5 hata payı ile $k \Delta L R$ katsayısı \%10 hata payı ile anlamlıdır. Newey-West tahmincisinde $\mathrm{F}$ testi $\% 10$ hata payı ile anlamlıyken, klasik EKK yöntemi ile yapılan tahminde R-kare değeri yaklaşık 0,12 ve $\mathrm{F}$ testi \%5 ile anlamlıdır. Çıktı sonuçlarına istinaden tahmin edilen modeller aşağıda verilmiştir. 
Tahmin edilen genel model

$\triangle L K F_{i}=1,00-0,16 \triangle L R_{t}+0,22 k \triangle L R_{t}$

2005Ç1-2009Ç1 ve 2011Ç4-2020Ç1 dönem için geçerli tahmin;

$\triangle L K F_{i}=1,00-0,16 \triangle L R_{t}+0,22 k \triangle L R_{t}$

2009Ç2-2011Ç3 dönemi için geçerli tahmin;

$\triangle L K F_{i}=1,00+0,06 \triangle L R_{t}$

Tahmin sonuçları göstermektedir ki 2008 Küresel Finansal Krizinin etkisini gösterdiği 2009Ç2 ve 2011 Ç3 arası dönem dışında faizler ile kira/fiyat oranı arasında ters yönlü bir ilişki vardır. Buna göre mortgage faizlerindeki \%1'lik bir artış konutlar için kira/fiyat oranını yaklaşık \%0,16 düzeyinde düşürmektedir. Bununla birlikte 2008 krizinde mortgage sisteminin yol büyüttüğü balonun patlaması, bu ilişkinin yönünü kısa dönem için de olsa değiştirmiş ve faizler ile kiralar arasında doğrusal bir ilişki ortaya çıkmıştır.

Belirtmek gerekir ki, anlamsız olan sabit katsayının denklemlerde kullanıldığı hali, bağımlı değişkenin e tabanında logaritmik olmasından dolayı, katsayının e tabanında ters logaritmasının alınmış halidir. Sabit katsayı anlamsız olduğundan yorumlanmamıştır.

\section{SONUÇ VE ÖNERI}

Çalışma kapsamında günümüzün en yaygın borçlanma aracı banka kredilerinin ekonomideki rolü ve kira/fiyat değişkenlerine etkisi üzerinde durulmuştur. Buna göre sermayenin maliyetini belirleyen ticari banka kredileri özellikle sermaye yoğun üretim yapan sektör ve firmaların durumları üzerinde söz sahibidir. Bu nedenle ticari krediler, gelişmekte olan ülkeler için yapısal dönüşümün önemli bir aracıdır. Tüketici kredileri ise vade ve kredi kullanım miktarlarına göre belirli ürünlerin taleplerini etkilemektedir. Söz gelimi uzun vadeli tüketici kredilerinin maliyetlerinde yaşanan değişmeler konut ve taşıt gibi ürünlerin talebine etkide bulunurken, kısa vadeli krediler günlük tüketim ürünlerine olan talebi etkilemektedir. Bu nedenden ötürü tüketici kredilerinin görevi söz konusu ürünler arasında talep dengesini korumak, aşırı ya da eksik talep durumlarını engellemek ve aşırı maliyetli üretim yapan endüstrileri daraltıp, pozitif ölçek ekonomilerinin geçerli olacağı endüstrilere talep yaratarak verimliliği artırmaktır. Öte yandan genel anlamda kredilerin görevi ise fiyat ve kira dengesini sağlayarak aşırı kâr ya da rant gelirini engellemek, böylece gelir dağılımında eşitliği gerçekleştirmek ve korumaktır.

Çalışma içerisinde soyut biçimde işlenen kredi kullanımının fiyat ve kiralara etkisi, ABD konut piyasasında yapılan analiz ile ekonometrik olarak ölçülmüştür. Sonuçlar beklenilen yönde ve anlamlıdır. Tahmin sonucu 2005Ç1-2009Ç1 ve 2011Ç4-2020Ç1 arası dönem için $A B D^{\prime}$ de \%1'lik mortgage faiz oranının artması kira/fiyat oranını \%0,16 oranında azalmaktadır. Yapısal kırılmanın geçerli olduğu 2009Ç2-2011Ç3 dönemi için ise mortgage faiz oranındaki \%1'lik artış, kira/fiyat oranını \%0,06 oranında arttırmaktadır. Kriz sonrası kira/fiyat oranının faiz oranları ile ilişkisinin bu yönlü değişmesi dikkat çekicidir. Çalışma bu sonuçlar doğrultusunda politika yapıcıya ışık olmalıdır.

\section{REFERENCES}

Alioğulları, Z. H., Başkaya, Y., Bulut, Y., \& Kılınç, M. (2015). Türkiye'de Tüketici ve Ticari Kredilerin Cari Açikla Ilişkisi (No. 15/19). Research and Monetary Policy Department, Central Bank of the Republic of Turkey. https://EconPapers.repec.org/RePEc:tcb:econot:1519

Alkan, U. (2016). Finans Sektöründen Reel Sektöre Parasal Aktarım Mekanizması. Etkin.

Arslan, Y., \& Kanık, B. (2012). ABD Kira Enflasyonu ve Konut Fiyat Dinamikleri (No. 12/03). Research and Monetary Policy Department, Central Bank of the Republic of Turkey. https://EconPapers.repec.org/RePEc:tcb:econot:1203

Bagehot, W. (1873). Lombard Street: A Description of the Money Market. E. P. Dutton and Company. https://EconPapers.repec.org/RePEc:hay:hetboo:bagehot1873

Balkaş, K. (2004). Kredi Kavramı ve Sektör Kredilerine Göre Türkiye'deki Belli Başlı Sektörlerin Analizi [Yüksek Lisans Tezi, Ankara Üniversitesi]. https://dspace.ankara.edu.tr/xmlui/handle/20.500.12575/27828

Bilgin, M. H., \& Kartal, F. (2009). Türkiye'de Enflasyon ve Bankacılık Sektörü Kredileri: 2002-2008 Dönemi Üzerine Bir İnceleme. Maliye ve Finans Yazıları, 1(85), 65-78.

Breusch, T. S. (1978). Testıng For Autocorrelatıon In Dynamıc Lınear Models. Australian Economic Papers, 17(31), 334-355. https://doi.org/10.1111/j.1467-8454.1978.tb00635.x

Breusch, T. S., \& Pagan, A. R. (1979). A Simple Test for Heteroscedasticity and Random Coefficient Variation. Econometrica, 47(5), 12871294. JSTOR. https://doi.org/10.2307/1911963 
Çeştepe, H., \& Yildirim, E. (2016). Türkiye'de Finansal Gelişme ve Ekonomik Büyüme ilişkisi. Uluslararası Yönetim iktisat ve İ̧̧letme Dergisi, $12(12), 12-26$

Ceylan, S., \& Durkaya, M. (2010). Türkiye'de Kredi Kullanımı - Ekonomik Büyüme ilişkisi. Atatürk Üniversitesi İktisadi ve İdari Bilimler Dergisi, 24(2), 21-35.

Daşdemir, E. N. (2017). The Effects of Debt on Debtors and The Economy: An Observational Test on Consumer Credit and Wages. iktisat Politikası Araştırmaları Dergisi, 5(1), 58-72.

Dickey, D. A., \& Fuller, W. A. (1979). Distribution of the Estimators for Autoregressive Time Series With a Unit Root. Journal of the American Statistical Association, 74(366), 427-431. JSTOR. https://doi.org/10.2307/2286348

Donald W. K. Andrews. (1993). Tests for Parameter Instability and Structural Change With Unknown Change Point. Econometrica, 61(4), 821856. JSTOR. https://doi.org/10.2307/2951764

Durbin, J., \& Watson, G. S. (1950). Testing for Serial Correlation in Least Squares Regression: I. Biometrika, 37(3/4), 409-428. JSTOR. https://doi.org/10.2307/2332391

Godfrey, L. G. (1978). Testing Against General Autoregressive and Moving Average Error Models when the Regressors Include Lagged Dependent Variables. Econometrica, 46(6), 1293-1301. JSTOR. https://doi.org/10.2307/1913829

Jarque, C. M., \& Bera, A. K. (1987). A Test for Normality of Observations and Regression Residuals. International Statistical Review / Revue Internationale de Statistique, 55(2), 163-172. JSTOR. https://doi.org/10.2307/1403192

Kar, M., \& Pentecost, E. J. (2000, December). Financial Development and Economic Growth in Turkey: Further Evidence on the Causality Issue. Department of Economics. Economic Research.

Kaya, A., Gülhan, Ü., \& Güngör, B. (2013). Türkiye Ekonomisinde Finans Sektörü Ve Reel Sektör Etkileşimi. Akademik Araştırmalar ve Çalışmalar Dergisi (AKAD), 5(8), 2-15. https://doi.org/10.20990/aacd.45324

King, R. G., \& Levine, R. (1993). Finance, entrepreneurship and growth. Journal of Monetary Economics, 32(3), 513-542. https://doi.org/10.1016/0304-3932(93)90028-E

Monetary Data: FRED St. Louis Fed. (2020). Federal Reserve Economic Data St. Louis Fed. https://fred.stlouisfed.org/series/BOGMBASE

Newey, W. K., \& West, K. D. (1987). A Simple, Positive Semi-Definite, Heteroskedasticity and Autocorrelation Consistent Covariance Matrix. Econometrica, 55(3), 703-708. JSTOR. https://doi.org/10.2307/1913610

Öğünç, F., \& Sarikaya, Ç. (2015). Enflasyonu Aciklamada Kredilerin Bilgi Degeri (No. 15/12; Issue 1512). Research and Monetary Policy Department, Central Bank of the Republic of Turkey. https://ideas.repec.org/p/tcb/econot/1512.html

Patrick, H. T. (1966). Financial Development and Economic Growth in Underdeveloped Countries. Economic Development and Cultural Change, 14(2), 174-189. JSTOR.

Robinson, J. (1952). The Rate of Interest: And Other Essays. Macmillan. https://books.google.com.tr/books?id=NFAPAQAAIAAJ

Schumpeter, J. (1911). The Theory of Economic Development. Cambridge.

Tobin, J. (1969). A General Equilibrium Approach To Monetary Theory. Journal of Money, Credit and Banking, 1(1), 15-29. JSTOR. https://doi.org/10.2307/1991374

White, H. (1980). A Heteroskedasticity-Consistent Covariance Matrix Estimator and a Direct Test for Heteroskedasticity. Econometrica, 48(4), 817-838. JSTOR. https://doi.org/10.2307/1912934 